\title{
Baseline CD8 T-cell activation is not associated with survival in ATLL
}

\author{
Graham P Taylor, Lucy Cook, Jana Haddow* \\ From 17th International Conference on Human Retroviruses: HTLV and Related Viruses \\ Trois llets, Martinique. 18-21 June 2015
}

Adult T-cell lymphoma/leukaemia (ATLL) is known to be associated with poor immune response. Currently, it is not clear whether this is contributory to, or the consequence of the development of ATLL. In the National Centre for Human Retrovirology (NCHR) in London, we measured CD8/DR expression (a marker of T-cell activation) at ATLL presentation in our cohort of patients and compared these findings with a control population of aged-matched patients with myelopathy (HAM) and asymptomatic carriers (AC). The normal range for CD3+ CD8+ HLA-DR in HTLV-1 uninfected adults is $5.7 \%-38.2 \%$. The median overall survival status in our cohort of patients with ATLL $(\mathrm{n}=53)$ is 9 months for acute subtype (range 3-22 months), lymphoma subtype 13.9 months (range 1-135 months), chronic subtype 64 months (range 8-144 months) and smouldering subtype 115 months. The median CD3+ CD8+ HLA-DR for AC was $25 \%$ (range $11-76 \%, n=20$ ), $44 \%$ HAM (range $19-80 \%, \mathrm{n}=20$ ) and $45 \%$ for all ATLL subtypes (range $9-87 \%, \mathrm{n}=26$ ). By ATLL subtype: acute $58 \%$ (range $22-72 \%, n=5$ ), lymphoma $43.5 \%$ (range $11-80 \%, n=10$ ), chronic subtype $41 \%$ (range $23-60 \%, n=9$ ), cutaneous $50 \%(\mathrm{n}=1)$, smouldering subtype $46 \%(\mathrm{n}=1)$. These data show that there is a significant increase in CD3+CD8+ HLA-DR expression in all ATLL subtype compared with $\mathrm{AC}$ and similar to that observed in patients with HAM. CD3+CD8+ HLA-DR expression is most marked in the acute subtype which is also associated with shortest survival. Despite evidence of CD8 T-cell activation this does not appear to be protective or associated with improved survival.

Published: 28 August 2015

* Correspondence: Jana.Haddow@imperial.nhs.uk

The National Centre for Human Retrovirology (NCHR), Imperial College Healthcare NHS Trust, St. Mary's Hospital, London, UK
doi:10.1186/1742-4690-12-S1-P70

Cite this article as: Taylor et al: Baseline CD8 T-cell activation is not associated with survival in ATLL. Retrovirology 2015 12(Suppl 1):P70.
Submit your next manuscript to BioMed Central and take full advantage of:

- Convenient online submission

- Thorough peer review

- No space constraints or color figure charges

- Immediate publication on acceptance

- Inclusion in PubMed, CAS, Scopus and Google Scholar

- Research which is freely available for redistribution
( Bīomed Central
C Biomed Central

(C) 2015 Taylor et al. This is an Open Access article distributed under the terms of the Creative Commons Attribution License (http:// (c) 2015 Taylor et al. This is an Open Access article distributed under the terms of the Creative Commons Attribution License (http://
creativecommons.org/licenses/by/4.0), which permits unrestricted use, distribution, and reproduction in any medium, provided the original work is properly cited. The Creative Commons Public Domain Dedication waiver (http://creativecommons.org/publicdomain/ zero/1.0/) applies to the data made available in this article, unless otherwise stated. 